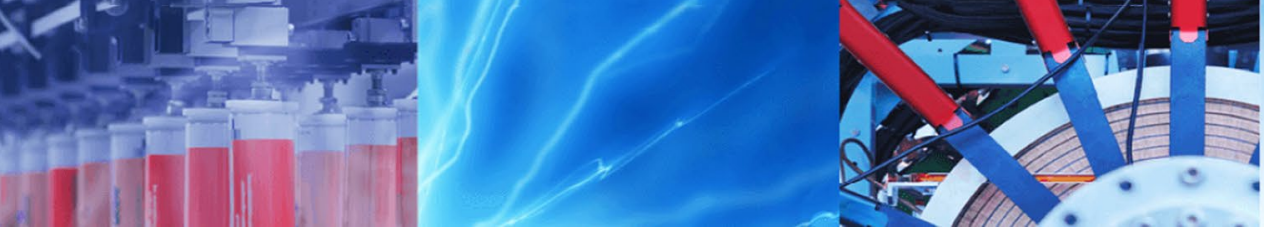

Research Article

\title{
Impact of microbial air quality in preschools on paediatric respiratory health
}

Pavithra Madamarandawala ${ }^{1}$ (D) $\cdot$ Yugani Weerasinghe $^{1}$ (D) $\cdot$ Dilami Pathiraja $^{2} \cdot$ Anuradha Ekanayake $^{1}$ (D) Dushantha Madegedara $^{2}$ (i) . Dhammika Magana-Arachchi ${ }^{1}$ (i)

(c) Springer Nature Switzerland AG 2019

\begin{abstract}
Microbial air quality (MAQ) is unambiguously linked with one's health particularly in pulmonology. Children remain more vulnerable in acquiring airborne infections than adults. MAQ studies and management are being implemented in developed countries, yet such information and actions are scarce in developing countries. Herein, we aimed to determine the indoor and outdoor airborne microbial concentrations in a rural versus urban perspective and their association with paediatric respiratory health. Preschools, one representing an urbanized and the other, a rural area, from Kandy, Sri Lanka, were considered. Respiratory health of 146 children (age; 3-6 years) was examined, and questionnaire-based information was obtained from their parents. Air samples were taken using natural sedimentation, single-stage viable sampler and fine particulate sampler to calculate the total microbial and culturable counts. Inhalation dose rates were calculated as per standard reference values. Micro-organisms were identified using $16 \mathrm{SrRNA}$ sequencing. Accordingly, $57.97 \%(n=40)$ urban and $31.17 \%(n=24)$ rural subjects suffered from at least one respiratory disease, upper respiratory tract infections, rhinitis, wheeze, etc. High total microbial counts $\left(\mathrm{cells} / \mathrm{m}^{3}\right.$ ) were seen in urban preschool (indoor: $4.66 \times 10^{5} \mathrm{vs} .2 .45 \times 10^{5}$, outdoor: $4.29 \times 10^{4}$ vs. $\left.2.74 \times 10^{4}\right)$. Inhalation dose rates were high in urban preschool, both indoor and outdoor $\left(2.00 \times 10^{4}\right.$ and $1.05 \times 10^{4}$ cells $/ \mathrm{kg}$ day). Irrespective of the site, indoor microbial counts were high and majority were opportunistic pathogens: Pseudomonas stutzeri, P. fluorescens, P. putida, Brevundimonas diminuta, Enterobacter cloacae, Bacillus pumilus, Acinetobacter calcoaceticus, B. cereus, Pseudoescherichia vulneris and Morganella morganii. Accordingly, observed dynamics can be a risk factor for the higher respiratory disease prevalence seen among urban preschoolers.
\end{abstract}

Keywords Microbial air quality $\cdot$ Paediatric respiratory health $\cdot$ Opportunistic pathogens $\cdot$ Inhalation dose rate

\section{Introduction}

Micro-organisms are ubiquitous in atmosphere and surroundings. Over the last decade, aspects related to air microbiology received ample attention of researchers specifically on microbial air quality (MAQ)- and exposurerelated health issues [1-3]. Airborne micro-organisms (AM) are considered as a serious concern in pulmonology. Their involvement influences the onset and complication of diseases particularly in the respiratory system [4]. Impact of being exposed to AM has been discussed with regard to diverse indoor and outdoor settings such as healthcare facilities, office buildings, educational settings and deserts [5-7]. The importance of routine monitoring of MAQ has been emphasized elsewhere, and such research findings are now utilized in air quality management in developed countries. Since 2004, the South Korean ministry of environment took initiatives in maintaining the air quality of

Electronic supplementary material The online version of this article (https://doi.org/10.1007/s42452-019-1306-6) contains supplementary material, which is available to authorized users.

Dhammika Magana-Arachchi, dhammika.ma@nifs.ac.lk| ${ }^{1}$ National Institute of Fundamental Studies, Kandy, Sri Lanka. ${ }^{2}$ Respiratory Diseases Treatment Unit, General Teaching Hospital, Kandy, Sri Lanka.

SN Applied Sciences (2019) 1:1280 | https://doi.org/10.1007/s42452-019-1306-6

Received: 22 June 2019 / Accepted: 18 September 2019 / Published online: 25 September 2019 
public health facilities in their country [3]. In 2009, World Health Organization (WHO) gave priority to studies relevant to indoor air pollutants including AM [8]. Many countries have set reference standard values for indoor and outdoor microbial counts; for example, in China, indoor air quality standard (GB/T18883-2002) is 2500 CFU/ $\mathrm{m}^{3}$ [6]. Accordingly, all regions of the world need prevention of health issues related to AM. On this facet, facts and details with regard to indoor and outdoor AM in developing countries need to be investigated further to administer necessary control strategies.

Microbial properties differ as per the environment as they tend to adapt themselves to the conditions they face. Moreover, drastically different microbial communities and concentrations were described even within different locations of the same premises [5]. Also, there is evidence that the concentration and composition of AM vary with the level of air pollution [9]. Hence, it is essential to understand regionally how AM differ in face of air pollution and its impact on one's health. As per the literature, most of the research on outdoor air focuses on chemical pollutants $[10,11]$. Thus, more studies are in need to arrive into agreements regarding biological aspects of airborne particles. In contrast, indoor air quality is equally important as outdoors as the time we spent indoors is generally higher than outdoors: approximately $90 \%$ [12]. WHO identified indoor air quality as the eighth most important risk factor for global disease burden [13]. Thus, it is of timely requirement to study AM and their impact, especially for the protection of susceptible groups like children and immunecompromised individuals [3]. Because of relevance to children, studies centred on schools are budding today; however, information is still insufficient, especially with respect to comparable identification of $\mathrm{AM}$ and inhalation doses $[2,14,15]$.

Children spend the majority of their time indoors, either at preschool, day-care centre or at home, while some hours are spent outdoors playing. They are more prone to acquire infections, especially those of airborne origin, than adults [16]. Acute respiratory infections (ARI) are the leading cause of child mortality in developing countries accounting for 1.3 million deaths annually [17]. Worldwide, tropics hold significant percentage of cases: India-14\% [18], Nepal-28.4\%, Thailand-18.2\% and Vietnam-27.9\% in 2017 [19]. The scenario is reasonably similar in Sri Lanka; in 2015, respiratory diseases (most common being acute upper and lower respiratory infections (ALRI, AURI), asthma, bronchiolitis, pneumonia and tonsillitis) were the third commonest cause of hospitalization at all ages [20]. Asthma shows a worldwide increase, 2013 prevalence being 235 million [21]. Reported percentages of wheeze, asthma or physician-diagnosed asthma among Sri Lankan early adolescents were 16.7\%, 10.7\% and $14.5 \%$ respectively. During $2000-2001,10-15 \%$ of reported wheeze cases were severe, most leading to pneumonia and/or asthma [22]. Alarmingly, a considerable portion of the country's total medical expenditure was required for respiratory diseases: $7.2 \%-2005$ (13.4\% allocated for non-communicable diseases was required for asthma management in 2013), and hence, they impart an additional economic burden for the country [23]. As such, the burden of childhood respiratory diseases persists notably in many countries including Sri Lanka. The potency of risk factors such as climate changes and air pollution is being researched elsewhere; however, sufficient pieces of evidence are still limited [24].

Herein, we conducted a study to investigate the impact of distribution of indoor and outdoor airborne microorganisms on the respiratory disease prevalence of preschool children. Kandy, one of the most rapidly urbanizing districts in Sri Lanka, was selected as our study area. For comparison of the impact of air pollution level on microbial dynamics, study sites were selected as representatives of a highly traffic-congested urban area and a less congested rural area in the district. As Kandy bears features similar to developing cities in tropics, the study can be considered as a resemblance in the region.

\section{Materials and methods}

\subsection{Study area, study subjects, ethics and health assessment}

A total of 146 preschool children residing in Kandy, a district in Central Province, Sri Lanka (the second-most important district in the country), were included in the study (Fig. 1). Spanning over an area of $1940 \mathrm{~km}^{2}$, the district bears a permanent population of around $>170,000$ and a daily transient population around 100,000 [25]. Majority of the population is centred at the capital of the district Kandy, within a highly urbanized area of $25 \mathrm{~km}^{2}$, while the environment outside is essentially rural. The capital experiences a daily traffic flow of nearly 100,000 vehicles, while no significant traffic is reported from rural areas. Preschool children were selected such that one cohort (urban cohort, $n=69$ ) represented a preschool in the capital (P1) and the other (rural cohort, $n=77$ ) represented a preschool in rural area (P2) of the Kandy district.

Information on age, sex, previous and current health status was gathered using an interviewer-administered questionnaire presented to their parents. Children were examined by a panel of consultant respiratory physicians, and symptomology of any prevailing respiratory disease/s was recorded. Approval for the study was obtained from 


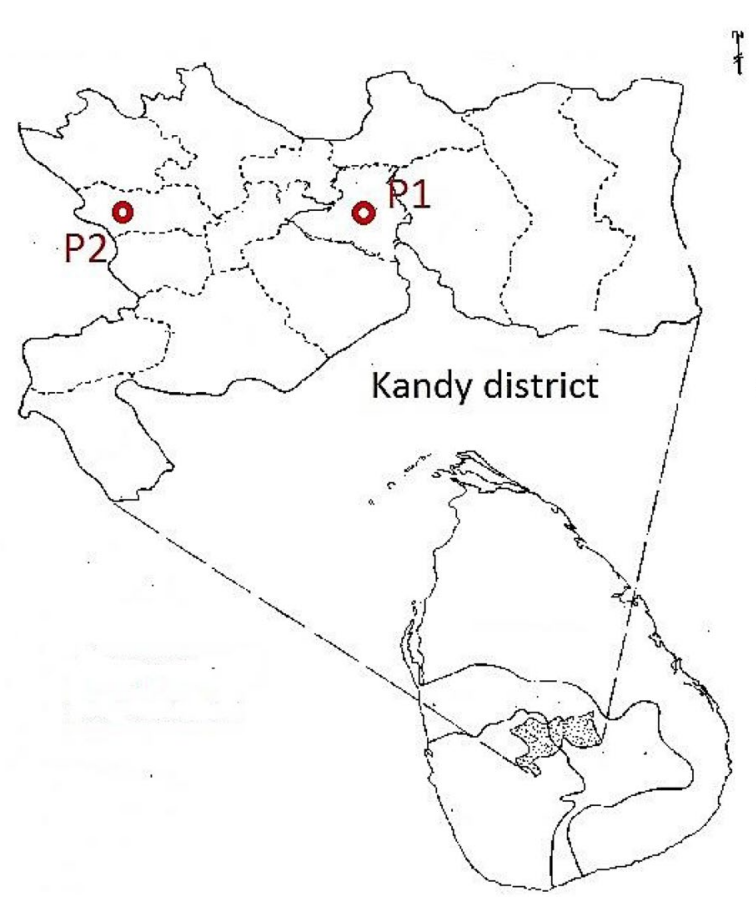

Fig. 1 Location of the selected urban preschool (P1) and rural preschool (P2) in a Sri Lankan map

the Ethical Review Committee of General Teaching Hospital, Kandy, Sri Lanka.

\subsection{Study site selection and air sampling}

Air sampling was conducted on nonrainy days in August-December 2017: during preschool working hours: $8.30 \mathrm{am}-12.00 \mathrm{pm}$. Details on indoor and outdoor temperature and a total number of occupants were noted at both premises (see supplementary table S1). For air sampling, one passive and two active methods were adopted as summarized in Fig. 2. Three indoor and three outdoor sites were selected for the passive natural sedimentation method (NSM). Active sampling was conducted using calibrated air samplers single-stage viable particle sampler (viable Andersen cascade impactor, Tisch, USA-28.3 ALPM) and fine particulate air sampler (APM 550 system, Envirotech Pvt. Ltd., India- $1 \mathrm{~m}^{3} / \mathrm{h}$ ) as per the manufacturer's guidelines. It was ensured that at all sites, all practices were done under similar conditions, and for each sampling event, triplicates were taken. Sampling was done at $1 \mathrm{~m}$ above the ground (average breathing zone of preschool children) for durations as listed in Fig. 2. Luria-Bertani (LB) medium (Alfa Aesar Co., Inc) was used for all microbiological purposes, and sterility checking was conducted for each lot of media prior to sampling.

\subsection{Enumeration of micro-organisms in air samples}

Plate count method was adopted for total culturable count (TCC) after 48-h incubation of NSM plates at room temperature, $\mathrm{RT}\left(25 \pm 3^{\circ} \mathrm{C}\right)$ [26]. For the total microbial count (TMC), filter papers aseptically removed from air samplers were cut into pieces, suspended in sterile Milli-Q water $(8 \mathrm{ml}$, Whatman No 5 and $4 \mathrm{ml}$, fine particulate air sampler filter papers provided by the manufacturer) and allowed to be shaken for $2 \mathrm{~h}$ at $95 \mathrm{rpm}$ in a laboratory orbital shaker (ORBITEK, Scigenics Biotech., India). One millilitre of the above extract was used for fluorescence enumeration of total microbial cells (both live and dead) using a nucleic acid gel stain. In brief, $2.5 \mu$ l of $1 \times$ SYBR Green I dye (Promega, USA) was mixed with $1 \mathrm{ml}$ of the filter paper extract, incubated in dark for $15 \mathrm{~min}$ and transferred to a surfacesterilized, gridded Sedgewick rafter counting cell (Wildco 1801-G20, USA). The average cell count per unit field $(1 \mu \mathrm{l})$
Fig. 2 Outline of air sample collection methodology

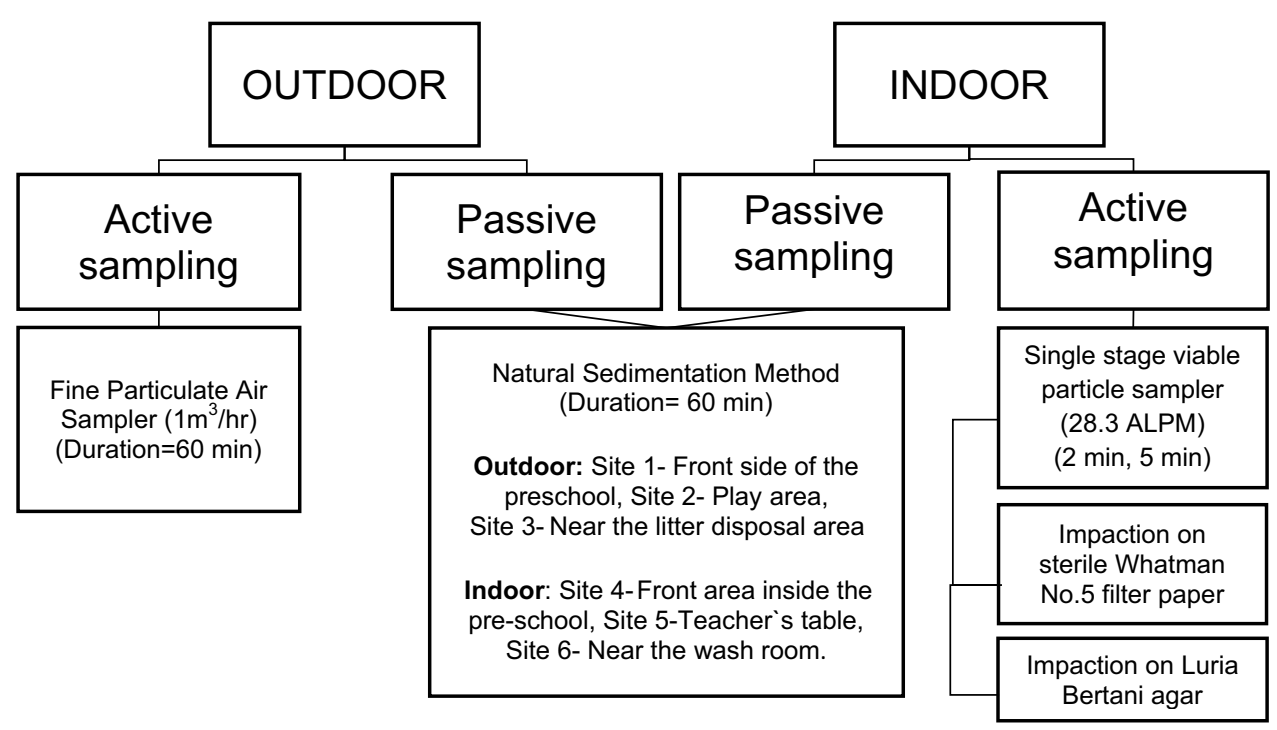

SN Applied Sciences A SPRINGER NATURE journa 
was obtained by manual counting using a fluorescence microscope (CLx41, Olympus), and the values were used to calculate the TMC by extrapolating to the entire volume $(1 \mathrm{ml})$ [27]. Extract prepared using an autoclaved Whatman No. 5 filter paper was used as the negative control.

\subsection{Molecular identification of bacteria in air samples}

One hundred microlitres of the filter paper extract was spread plated on LB agar, and the plates were incubated at RT $\left(25 \pm 3^{\circ} \mathrm{C}\right)$ along with NSM plates for $24-48 \mathrm{~h}$. Each morphologically dissimilar bacterium was culturally isolated, and DNA was extracted using the modified cetyltrimethylammonium bromide (CTAB) method [28].

Polymerase chain reaction (PCR) was carried out in a real-time PCR instrument (RotorGeneQ, Qiagen, Germany) using universal bacterial $16 \mathrm{~S}$ rDNA primers 27F (5'-AGA GTT TGA TCM TGG CTC AG-3') and 1492R (5'-GGY TAC CTT GTT ACG ACT T-3') [29]. Reaction was carried out in a $25 \mu \mathrm{l}$ mixture containing $375 \mathrm{ng}$ bacterial DNA, $0.1 \mathrm{mM}$ each dNTP (Promega, USA), $0.4 \mu \mathrm{M}$ each forward and reverse primer, $1 \times$ Taq buffer (Promega, USA), $1.5 \mathrm{mM} \mathrm{MgCl}_{2}$ (Promega, USA), one unit Taq DNA polymerase (Promega, USA). The thermo-cycle program was set as: $94^{\circ} \mathrm{C}-2$ min: initial denaturation, followed by 40 cycles of denaturation at $94^{\circ} \mathrm{C}-1 \mathrm{~min}$, annealing at $50^{\circ} \mathrm{C}-1 \mathrm{~min}$ and elongation at $70^{\circ} \mathrm{C}-2 \mathrm{~min}$, and final extension at $70^{\circ} \mathrm{C}-20 \mathrm{~min}$ [30]. Amplified DNA was visualized using a gel documentation system (Syngene, UK) after electrophoresis in 1.5\% agarose and ethidium bromide staining. Amplicons were purified using a gel extraction kit (Promega, USA) and were subjected to Sanger sequencing using a commercial facility (Macrogen Inc., Korea).

\subsection{Data analysis}

TMC values were used to calculate the inhalation dose rates of children during the hours spent at the preschool premises using the following equation:

$D=\frac{\mathrm{BR}}{\mathrm{BW}} \times C \times \mathrm{OF} \times N$

in which $D$ is the age-specific dose (cells/kg day); BR is the age-specific weighted average breathing rate $(\mathrm{L} / \mathrm{min})$; $\mathrm{BW}$ is the age-specific body weight $(\mathrm{kg}) ; C$ is the total microbial count (cells $/ \mathrm{m}^{3}$ ); OF is the occupancy factor; and $N$ is the time spent per day in the location of exposure ( $\mathrm{min} /$ day) [2]. Reference values for BR and BW were retrieved from USEPA data [31]; accordingly, for calculations of indoor air inhalation dose rates, the "sedentary/passive" level ( $\mathrm{BR}=4.5 \mathrm{E}-03 \mathrm{~m}^{3} / \mathrm{min}$ ) was selected, as children were mostly seated and engaged in learning activities. For calculations of outdoor air inhalation dose rate, "moderate intensity" level $\left(2.1 \mathrm{E}-02 \mathrm{~m}^{3} / \mathrm{min}\right)$ was selected as children were used to play around in outdoors. OF was considered 1 as the preschools had scheduled timetables for all the days. $N$ was considered 180 min for indoor calculations and $30 \mathrm{~min}$ for outdoor calculations.

Statistical analysis was conducted using Microsoft ${ }^{\oplus}$ Excel (office 2010) and SPSS ${ }^{\circledR}$ statistical software version 21 (IBM, USA). Anderson-Darling tests were conducted to check the normality of data, and Chi-square analysis and Fisher's exact test were conducted for data analysis. For all tests, $p<0.05$ was considered as statistically significant.

\section{Results}

\subsection{Profile of preschool children: demographics and distribution of respiratory diseases}

In total, 146 preschool children aged 3-6 years were included in the study (Table 1(A)). All the children were residents within a few metres from their preschools.

Respiratory rates of all the subjects were within the normal range as per PALS guidelines, 2018 (Table 1(B)), and none displayed bronchial breathing or cyanosis.

Figure 3 explains the distribution of respiratory diseases and symptoms among the subjects before and after the entrance to preschool. At the time of examination, a total of $57.97 \%(n=40)$ urban and $31.17 \%(n=24)$ rural preschoolers were suffering from at least one respiratory symptom. Statistically, the symptoms were more common among urban subjects (Chi-square value: 0.004 ). The increment of respiratory disease symptoms following entrance to preschool was significant in both groups (Fisher's exact test $p$ value: 0.000 ): $10.4 \%$ increment among rural preschoolers and $5.8 \%$ increment in urban preschoolers. Prior to entrance and following entrance to preschool, majority had multiple respiratory symptoms and cough was the most predominant among urban subjects.

\subsection{Microbial concentrations in indoor and outdoor preschool atmosphere}

Figure 4 illustrates the culturable microbial counts obtained at each site selected for NSM air sampling (see supplementary table S1). Irrespective of the site of sample collection (Fig. 4), rural preschool counts were high in indoor $\left(575.1 \pm 190.77 \mathrm{CFU} / \mathrm{m}^{2} /\right.$ $\min$ vs. $208.63 \pm 130.01 \mathrm{CFU} / \mathrm{m}^{2} / \mathrm{min}$ ) while urban preschool counts were high in outdoor atmosphere $\left(430.79 \pm 152.56 \mathrm{CFU} / \mathrm{m}^{2} / \mathrm{min}\right.$ vs. $337.386 \pm 98.07 \mathrm{CFU} /$ $\mathrm{m}^{2} / \mathrm{min}$ ). Accordingly, in indoor, the culturable counts were high at all sites of the rural preschool (indoor/ 
Table 1 Characteristics of preschool children:

(A) demographics and

(B) respiratory system examination information

\begin{tabular}{|c|c|c|}
\hline & Urban cohort & Rural cohort \\
\hline \multicolumn{3}{|l|}{ (A) Demographics } \\
\hline Total number of children & 69 & 77 \\
\hline Male/female ratio & $36 / 33$ & $44 / 33$ \\
\hline \multicolumn{3}{|l|}{ (B) Respiratory system examination information } \\
\hline Respiratory rate (per min) & 20.54 & 20.58 \\
\hline Rhonchi & $15.94 \%(n=11)$ & $3.89 \%(n=3)$ \\
\hline Crepts & $5.79 \%(n=4)$ & $2.59 \%(n=2)$ \\
\hline Presence of respiratory diseases prior to entrance to preschool & $52.17 \%(n=36)$ & $29.8 \%(n=23)$ \\
\hline Presence of respiratory diseases at the time of examination & $57.97 \%(n=40)^{*}$ & $31.17 \%(n=24)$ \\
\hline Increment of respiratory disease symptoms among subjects & $5.8 \% *$ & $1.37 \% *$ \\
\hline
\end{tabular}

\#Normal respiratory rate of children aged 3-6 years: 20-24 per min (PALS guidelines, 2018)

*Statistically significant $(p<0.05)$
Fig. 3 Distribution of respiratory diseases/symptoms among rural preschool children and urban preschool children, before and after the entrance to preschool

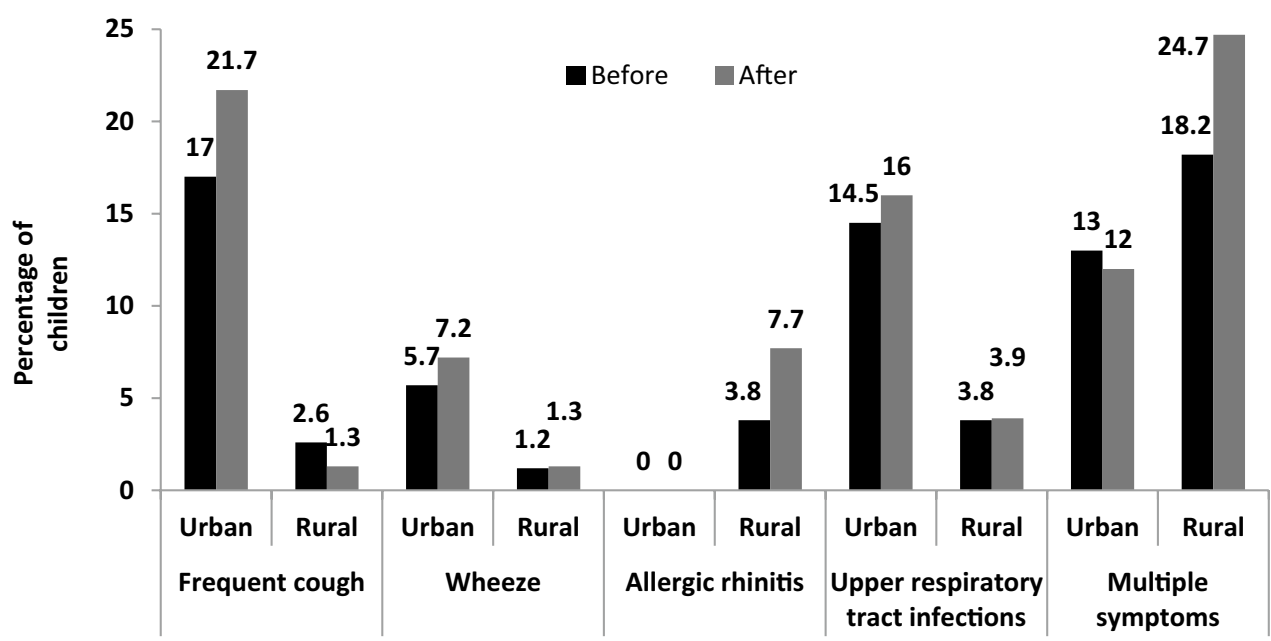

outdoor ratio $=1.71)$ and in outdoor, the culturable counts were high at all sites of the urban preschool (urban/rural ratio $=1.28$ ). Significantly, majority were gram-negative organisms.

However, as illustrated in Fig. 5 and Table 2, in both indoor and outdoor environments, total microbial counts were high in urban premises: indoor urban/ rural ratio $=1.90\left(4.66 \times 10^{5} \pm 1.28 \times 10^{5}\right.$ cells $/ \mathrm{m}^{3} \mathrm{vs}$. $2.45 \times 10^{5} \pm 1.21 \times 10^{5}$ cells $\left./ \mathrm{m}^{3}\right)$ and outdoor urban/ rural ratio $=1.56\left(4.29 \times 10^{4} \pm 8.92 \times 10^{3}\right.$ cells $/ \mathrm{m}^{3}$ vs. $2.74 \times 10^{4} \pm 2.18 \times 10^{3}$ cells $\left./ \mathrm{m}^{3}\right)$. As per indoor/outdoor ratio, in both premises, indoor TMCs were higher than outdoor TMCs by nearly ten times.

\subsection{Inhalation dose rate calculation}

Compared to rural preschool, inhalation dose rates were high in both indoor and outdoor environments of urban preschool $\left(2.00 \times 10^{4}\right.$ and $1.05 \times 10^{4}$ cells $/ \mathrm{kg}$ day $)$ (Table 2).

\subsection{Identification of airborne bacteria}

Identified micro-organisms (see supplementary table S2 for NCBI accession numbers) are listed in Fig. 6, amongst which Pseudomonas was the most dominant Genus. Pseudomonas stutzeri was isolated from outdoor air of both preschools and also from the indoor air of the rural preschool. Morganella morganii, Pseudomonas fulva and $P$. chlororaphis were isolated from outdoor air of both preschools. Similarly, P. fluorescens was isolated from indoor air of the rural preschool and the outdoor air of the urban preschool.

\section{Discussion}

The study overviewed the microbial air quality in the atmosphere surrounding preschools located in Kandy, the central city in Sri Lanka. Consequently, we encountered high microbial counts in indoors (indoor/outdoor ratio: $\mathrm{P} 110.86$ and $\mathrm{P} 2$ 8.94) amongst which opportunistic 


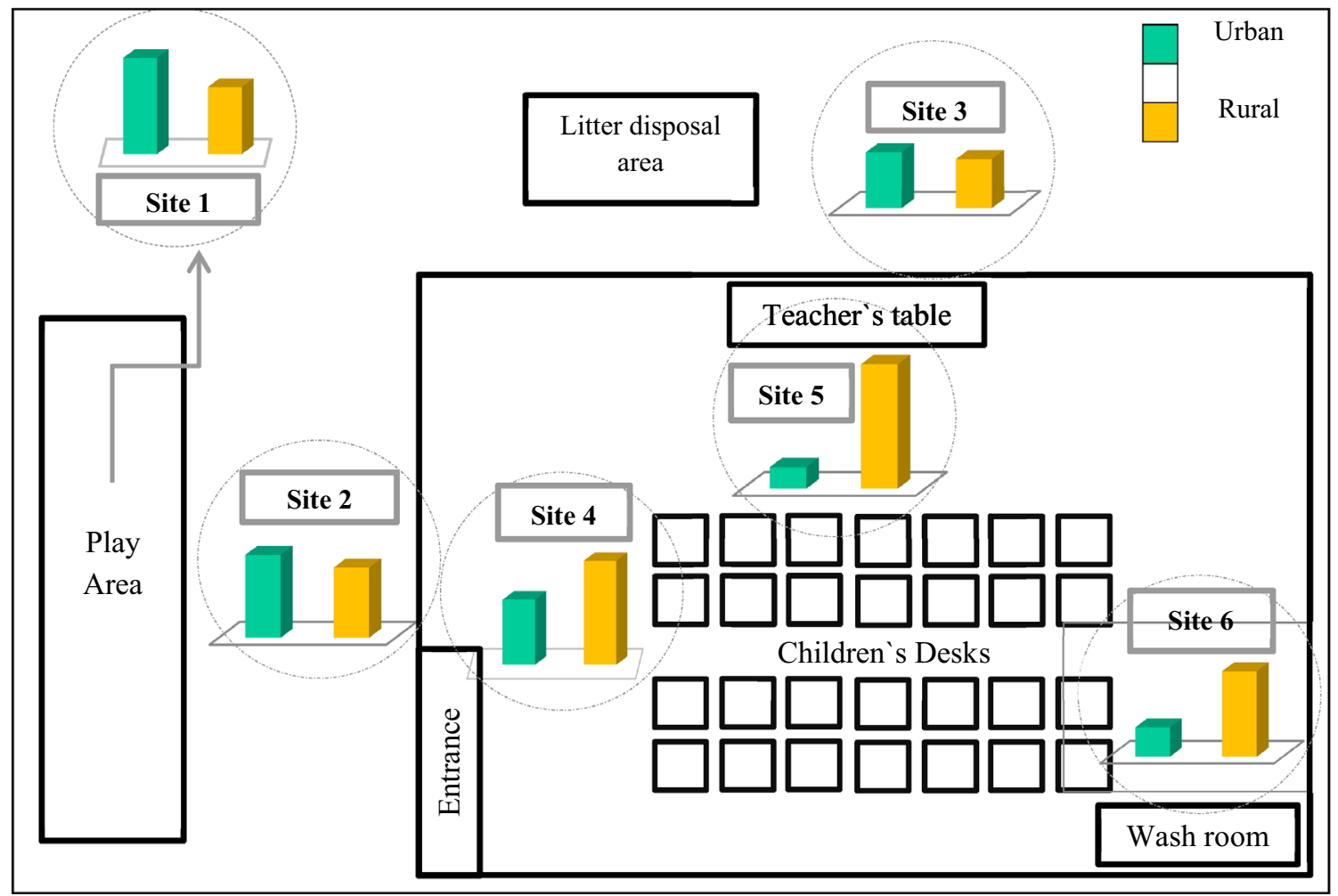

Fig. 4 Culturable counts obtained from natural sedimentation method (NSM) at each site selected in preschools. (Outdoor sites: Site 1 -front side of the preschool, Site 2-play area, Site 3-near

pathogens occupied a considerable proportion (Fig. 6). In previous studies also, indoor concentrations were greater than those of outdoors [15, 32]. The findings are of much importance since our subjects: preschool children, stay inside the premises within a considerable period of the day. As per WHO, indoors possess limited space for air circulation and in the absence of proper ventilation, microorganisms released from various sources tend to remain inside increasing the inhalation doses of occupants as seen in our study (Table 2) [13]. We should not disregard our results even though the numbers we obtained for inhalation dose rates were lower than the previous studies. However, compared to the few studies that report inhalation dose rates, the numbers we obtained were low [2]. Regarding TMCs, high values in P1 could be due to insufficient number of windows for ventilation compared to $P 2$ (see supplementary table S1). Furthermore, human occupancy has great influence on the surrounding microbial composition [12]. Activities, particularly talking, singing, sneezing and even scratching the skin, release numerous micro-organisms to the atmosphere. For instance, per event, sneezing releases 40,000 droplet particles approximately [5]. Moreover, such human activities can release infected aerosols if released from a diseased individual. the litter disposal area, indoor sites: Site 4-front side inside the preschool, Site 5-teacher's table, Site 6-near the washroom)

Such aerosols can increase cross infections, which could have influenced the increase in occurrence of paediatric respiratory diseases upon entering preschool in both cohorts of our study (Table 1) [6]. Besides, human activities like walking and running disturb the settled dust particles making them re-circulate in the atmosphere [12]. Previous studies have identified that Pseudomonas, Bacillus and Acinetobacter species are associated with dust particles [33]. In addition, the presence of an attached washroom could be another reason. Common washrooms are ideal sources of bio-aerosols specifically dominated by human-associated micro-organisms [34]. Even though inside dumps and moist walls are also sources of air microbes, we did not come across the same in our study sites [12]. Conversely, exposure time also affects one's respiratory health. Shortterm exposure to high microbial concentrations is more effective, but long-term exposure to low concentrations should not also be underestimated [35]. This explains our observation of high disease prevalence among urban preschoolers: $57.97 \%$ (those who were exposed to high inhalation dose rates) plus a considerable disease prevalence (which is not too low) among the rural preschoolers. Also, even though the microbial concentrations are comparatively low, it cannot be guaranteed that outdoor 
Fig. 5 Total microbial counts (TMC) and total culturable counts (TCC) in indoor and outdoor atmosphere of the selected rural and urban preschool premises and the gram nature of isolated bacteria (GN gram-negative, GP grampositive)

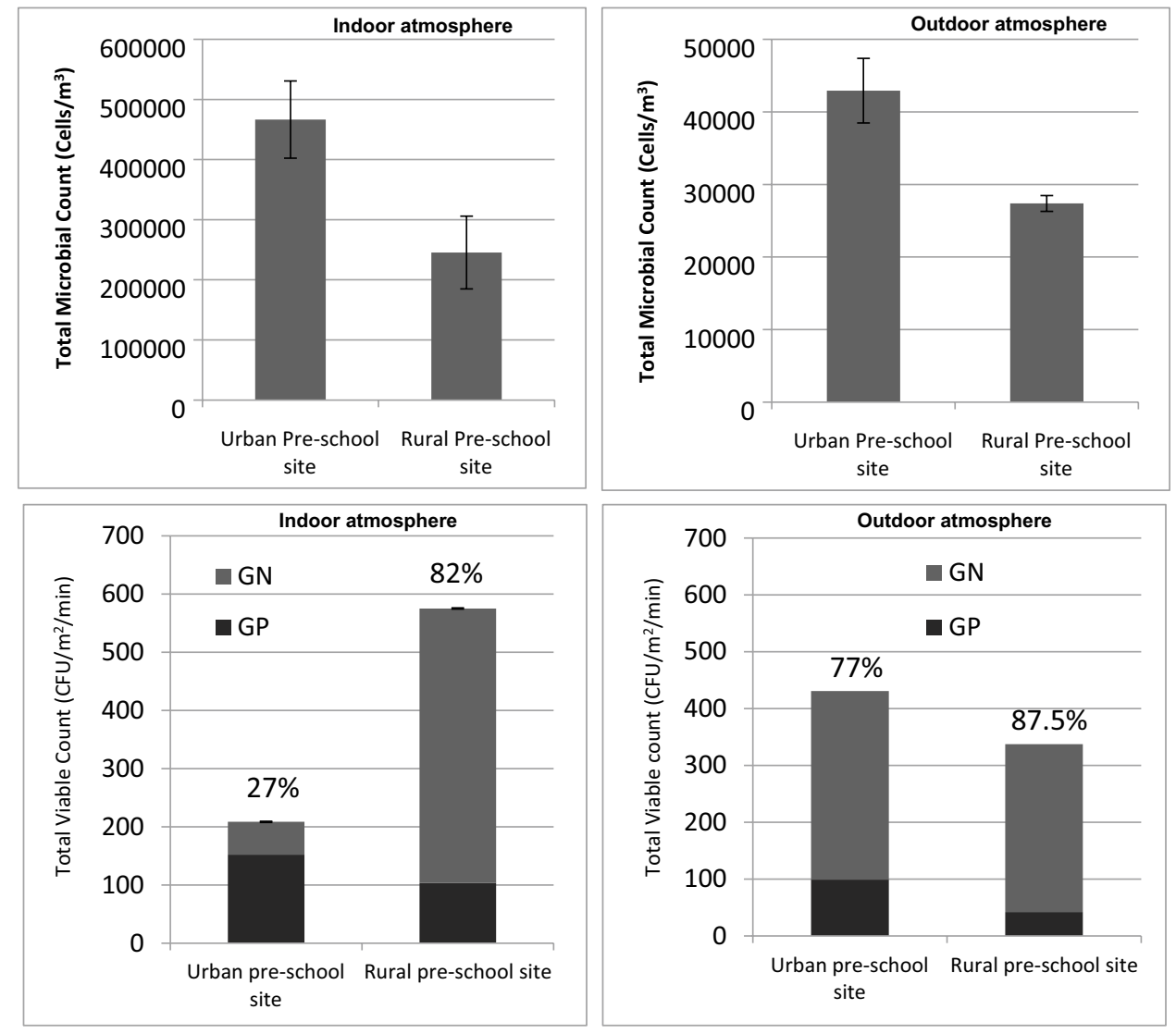

Table 2 Total microbial counts (TMC) of urban and rural preschools and associated inhalation dose rates

\begin{tabular}{|c|c|c|c|c|c|}
\hline & \multicolumn{2}{|l|}{ Urban preschool } & \multicolumn{2}{|l|}{ Rural preschool } & \multirow{2}{*}{$\begin{array}{l}\text { Urban/ } \\
\text { rural } \\
\text { ratio }\end{array}$} \\
\hline & $\begin{array}{l}\text { Total microbial count (cells } / \mathrm{m}^{3} \text { ) } \\
\text { Mean } \pm \text { SD }\end{array}$ & $\begin{array}{l}\text { Inhalation dose } \\
\text { (cells/kg day) }\end{array}$ & $\begin{array}{l}\text { Total microbial count (cells } / \mathrm{m}^{3} \text { ) } \\
\text { Mean } \pm \text { SD }\end{array}$ & $\begin{array}{l}\text { Inhalation dose } \\
\text { (cells/kg day) }\end{array}$ & \\
\hline Indoor & $4.66 \times 10^{5} \pm 1.28 \times 10^{5}$ & $2.00 \times 10^{4}$ & $2.45 \times 10^{5} \pm 1.21 \times 10^{5}$ & $1.50 \times 10^{3}$ & 1.90 \\
\hline Outdoor & $4.29 \times 10^{4} \pm 8.92 \times 10^{3}$ & $1.05 \times 10^{4}$ & $2.74 \times 10^{4} \pm 2.18 \times 10^{3}$ & $9.59 \times 10^{2}$ & 1.56 \\
\hline $\begin{array}{l}\text { Indoor/out- } \\
\text { door ratio }\end{array}$ & 10.86 & & 8.94 & & \\
\hline
\end{tabular}

is safer. For example, TCC value of the play area in P1 is above $500 \mathrm{CFU} / \mathrm{m}^{3}$, the permissible level recommended by American Industrial Hygiene Association [36]. The same was observed in P2, with respect to site 4 and site 5 in indoors. This could be possibly due to high human occupancy at the said sites. However, one should note that TCC values are not true representatives of the microbial composition of a place and the proportion is quite low when compared with the TMC values [37]. For good air quality management, one requirement is that the indoor TCCs should not surpass the outdoor TCCs by 350 CFU $/ \mathrm{m}^{3}$ [15]. In our study, both preschools have met the requirement.

In addition to exposure factors, impact of airborne micro-organisms on one's health is closely related to immunity of the individual. Children remain vulnerable to most of the infections owing to their developing immunity system [2]. Human lung mechanics develop significantly during 2-6 years of age. Any disorder that disturbs its development influences his/her future respiratory perspectives. Also, they inhale a higher dose of air per unit body weight, when compared to adults [2]. In view of that, children who were not previously exposed to high microbial concentrations would have been the most likely victims. Perhaps, this could be why we came across respiratory diseases among children who had minimal or no respiratory diseases prior to entrance to preschool. Also, we observed a trend towards developing multiple symptoms following admission to the preschool: $5.8 \%$ increase 


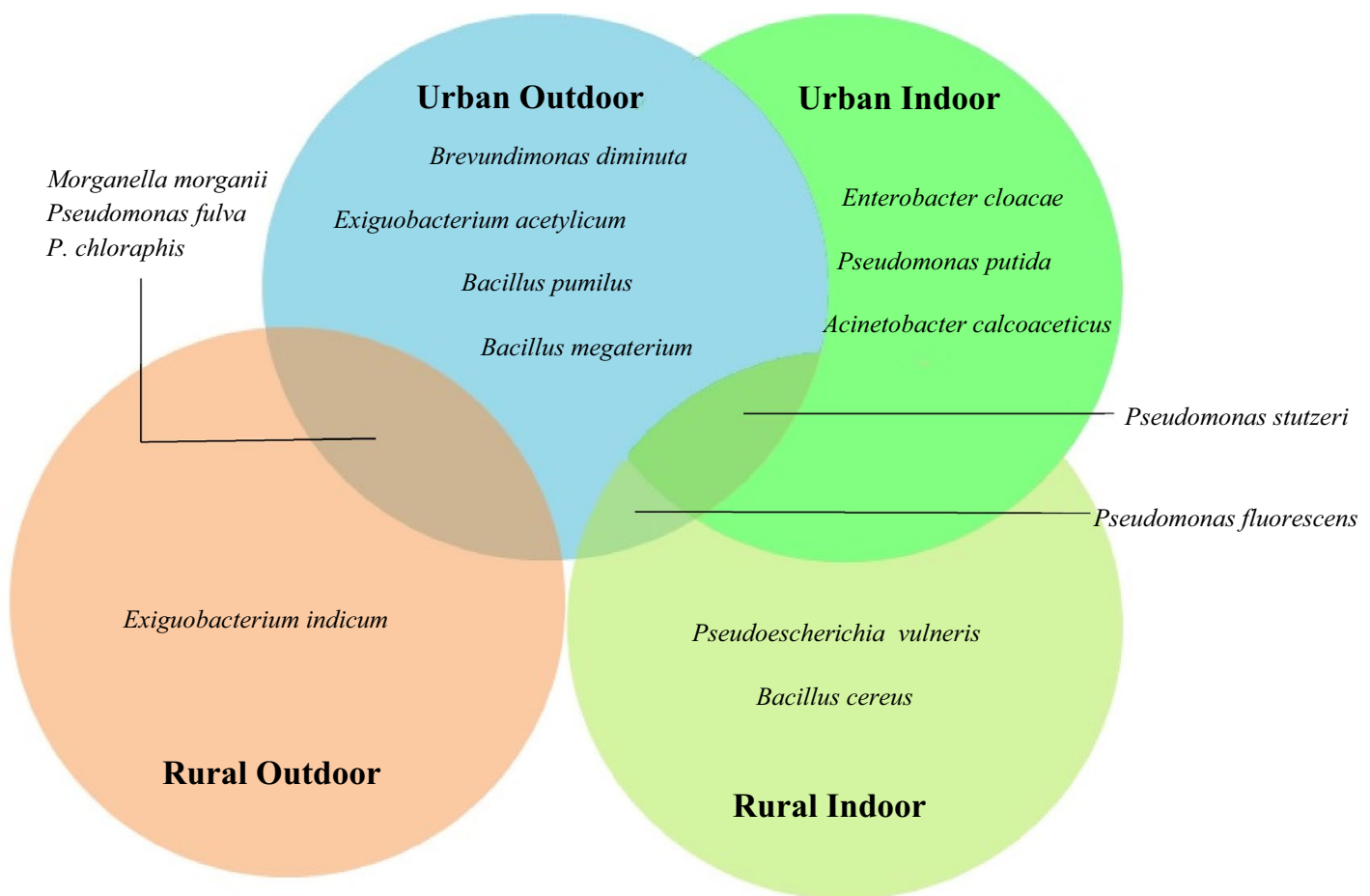

Fig. 6 Venn diagram depicting the organisms identified from the atmosphere surrounding the rural and urban preschool premises

in urban area and $1.37 \%$ in rural area (Fig. 3), perhaps due to weak immunity one gains as a consequence of any prevailing respiratory disorders.

Among the micro-organisms identified, majority were opportunistic pathogens (Fig. 6). Although direct associations of prevailing respiratory diseases in the cohorts and the identified micro-organisms cannot be established, it could be assumed that the pathogens play a role either in causation or in complication of prevailing respiratory diseases. Wheezing is significantly correlated with bacteria [38]. Furthermore, as per [39], species belonging to Pseudomonas, Enterobacter, Acinetobacter and Bacillus are directly associated with upper and lower respiratory tract infections. Pseudomonas sp. identified from both premises and both indoors and outdoors is a wellknown opportunistic pathogen, causing mild-to-severe respiratory complications. We came across $P$. stutzeri, $P$. fluorescens and $P$. putida which are cited as associated with respiratory infections; however, such information on P. fulva and P. chlororaphis is reported less [40]. We also encountered Brevundimonas diminuta, Enterobacter cloacae, Bacillus pumilus and Acinetobacter calcoaceticus from urban atmosphere and $B$. cereus and Pseudoescherichia vulneris from rural atmosphere which bear potential to cause respiratory diseases [40]. In addition, Morganella morganii cited as a pathogen that complicates existing respiratory disorders was also found in both sites [41]. Apart from respiratory diseases, they are also capable of causing other infections on skin and digestive system [42]. In Norway, short-term exposure to microbial agents was found to be responsible for both eye and respiratory illnesses among farmers [43]. In addition to direct contact with live micro-organisms, spores or dead particles can also trigger allergies and asthma [44]. However, we encountered allergic rhinitis only among rural preschoolers (Fig. 3). The original sources of identified bacteria could be diverse. As discussed, human oral and skin flora could get released to the atmosphere: for example, Enterobacter sp. is an inhabitant of both oral cavity and skin [45]. Outdoors, it could be soil-Enterobacter, Bacillus, Pseudomonas sp.; waterEnterobacter sp., Pseudomonas; plants-Pseudomonas sp.; and/or animals-Pseudomonas, Micrococcus sp. [46], etc. Among the organisms isolated, we encountered Brevundimonas sp. only in the urban premises (Fig. 6). Similarly, in a study done in Singapore, Brevundimonas sp. was isolated from urban atmosphere which accounted for $56 \%$ of its total micro-biome [47]. The high indoor/outdoor ratio we came across, also predicts that indoor sources could also be responsible for the air quality outdoors. In Europe, it was found that majority of bacteria in indoor air were of gram-positive nature [37]. However, we came across a similar observation only in the urban site (73\%, Fig. 4). The survival of AM generally depends on temperature, humidity, wind and other seasonal variations [37]. At low 
temperature, aerosols of gram-negative bacteria such as Pseudomonas and Enterobacter sp. survive their best. Critical situation in getting exposed to outdoor AM is that we cannot control these factors.

Atmospheric microbial load differs with air pollution level, and our results suggested the same. As per a study conducted in an inland city in China, the maximum TMC is observed at moderate air pollution level, i.e. at first, the TMC value increases with depletion of air quality and then it slightly decreases: excellent $\left(1.92 \times 10^{5} \pm 0.88 \times 10^{5}\right.$ cells/ $\left.\mathrm{m}^{3}\right)<\operatorname{good}\left(2.39 \times 10^{5} \pm 1.47 \times 10^{5}\right.$ cells $\left./ \mathrm{m}^{3}\right)<$ lightly polluted $\left(5.38 \times 10^{5} \pm 3.26 \times 10^{5}\right.$ cells $\left./ \mathrm{m}^{3}\right)<$ heavily polluted $\left(5.93 \times 10^{5} \pm 3.45 \times 10^{5}\right.$ cells $\left./ \mathrm{m}^{3}\right)<$ severely polluted $\left(7.23 \times 10^{5} \pm 3.49 \times 10^{5}\right.$ cells $\left./ \mathrm{m}^{3}\right)<$ moderately polluted $\left(7.38 \times 10^{5} \pm 4.43 \times 10^{5}\right.$ cells $\left./ \mathrm{m}^{3}\right)$ [9]. In our study, outdoor TMCs obtained for urban and rural premises were significantly different $\left(4.29 \times 10^{4} \pm 8.92 \times 10^{3}\right.$ cells $/ \mathrm{m}^{3}$ vs. $2.74 \times 10^{4} \pm 2.18 \times 10^{3}$ cells $/ \mathrm{m}^{3}$ ) and thus, TMC itself suggests being an ideal marker for air quality level in an environment. Bearing properties of a city in a developing tropical country, Kandy drives towards the list of polluted cities in the region. Recent studies revealed that Kandy city atmosphere has considerable percentages of heavy metals ( $\mathrm{Cr}, \mathrm{Mn}, \mathrm{Ni}, \mathrm{Cu}, \mathrm{Cd}, \mathrm{Zn}$ and $\mathrm{Pb})$, mainly traffic influenced [25]. Moreover, continuous constructions and incomplete fuel combustion contribute to the city air quality depletion. Atmospheric microbial load acts as an air quality indicator as it increases with air pollution up to a certain limit [9]. This explains our observation of high microbial counts in the urban atmosphere compared to the rural atmosphere: urban/rural ratio (outdoor) 1.56 and urban/ rural (indoor) ratio 1.90 (Table 2). Counts we obtained were correlative to previous studies done in Kandy city; accordingly, total bacterial concentrations ranged from $2.40 \times 10^{4}$ to $1.15 \times 10^{6}$ cells $/ \mathrm{ml}$ with the mean concentration of $5.87 \times 10^{5}$ cells $/ \mathrm{ml}$ [25]. In a study conducted in India, the industrialized area showed higher culturable bacterial counts $\left(781.6 \times 10^{4} \mathrm{CFU} / \mathrm{m}^{3}\right)$ compared to the residential area $\left(318 \times 10^{3} \mathrm{CFU} / \mathrm{m}^{3}\right)$ [48]. High pollution levels increase the ambient environmental temperature, ultraviolet exposure and reduce the concentration of dissolved oxygen per unit volume. Hence, micro-organisms are pressurized to adapt or die. Those which adapt tend to bear thick cell walls resistant to air pollutants, radiation and heat $[37,49]$. Brevundimonas diminuta and Acinetobacter calcoaceticus we came across only in urban atmosphere are reported as capable of surviving in high radiation [50]. Pigmentation and gram-negative majority we came across [51], therefore, could be consequences of the above situation. Alarmingly, the majority of pathogens are gram-negative, and thus, air pollution aids in better survival of resistant and potentially pathogenic micro-organisms in air. This could be why we came across high urban/rural ratio of microbial counts (Table 2). The air quality also influences the initial acquisition of bacteria such as Pseudomonas sp [52]. On the whole, air microbial dynamics with respect to air pollution leads to increased chances of developing respiratory infections and complicating existing respiratory failures [17].

However, there could be other factors influencing the high numbers of respiratory malfunctions as observed in $[53,54]$. For instance, a study done in China revealed that air pollutants bear the potential to cause rhinitis [53]. Impact of air pollution on health has been described elsewhere, and the effect seems a result of constitutive of various risk factors rather than one [53]. For example in our study, we observed that comparatively, the symptoms were more commonly seen among urban preschool children (Chi-square value: 0.004$)$. This information reconfirmed the results of a study done on respiratory disease prevalence of Sri Lankan children aged 7-10 years in Colombo, the capital of Sri Lanka [55]. Similar studies were conducted in diverse settings; in Nigeria, children under five suffering with ARI were found to be linked with high exposure to indoor airborne micro-organisms [36]. In certain other studies, the microbial counts observed were drastically different which could be due to different techniques used and due to the absence of standardization [2]. This is the first study of its kind in the South Asian region to compare indoor and outdoor air microbiota as well as the rural and urban air microbiota simultaneously considering the health impact on preschool children. The information we generated in a selected small cohort would open ways for advanced studies on indoor and outdoor air quality, pollution control and offer new insights in prevention of respiratory illnesses among preschool children not only in Sri Lanka but also in similar countries.

\section{Limitations}

The study focused majorly on bacteria although fungi and viruses are also influential in causation of respiratory diseases. Moreover, the study findings could be presented more strongly if the number of study sites was more than two. Also, as there can be many other risk factors, thorough investigations are required for better conclusions. In the absence of relevant data for inhalation dose rate calculations, we used reference values from USEPA database, which would be more meaningful if the data were generated from the same study subjects. Also, TCC values do not reflect the microbial composition truly as it is only a small proportion of the whole picture. Furthermore, since impingement can physically damage the cell walls of bacteria resulting in loss of viability, bacteria identified 
by culturing would not be a true resemblance in certain situations [37].

\section{Conclusions}

The organisms identified were opportunistic pathogens, and higher microbial counts were observed in the urban atmosphere when compared to the rural atmosphere. Irrespective of the study sites, indoor microbial counts were high in both premises. Observed higher microbial counts and presence of opportunistic pathogens could have been a risk factor for the higher respiratory disease prevalence seen among urban preschool children, whose symptoms were seen with statistical significance. Furthermore, inhalation dose rates were high among urban preschoolers. Hence, increasing dynamics of air microbiota w.r.t. air pollution should not be underestimated and thorough investigations should be conducted to evaluate its potential of causing respiratory malfunctions.

Acknowledgements The authors acknowledge the financial support given by the National Institute of Fundamental Studies, Kandy, Sri Lanka. We warmly thank head mistresses of the preschools, parents and all the participant children for their support to conduct the research. We also acknowledge Ms. S. Watagodakumbura, Mr. S. Rajapakse, Mr. Y. Jayawardana, Ms. L. Weerasundara, Mr. V. Gunarathne and Mr. A. Ahmed for their valuable assistance.

\section{Compliance with ethical standards}

Conflict of interest On behalf of all authors, the corresponding author states that there is no conflict of interest.

Informed consent of the participants As the study group is minors, informed consents were obtained by their legal guardian prior to sample collection.

\section{References}

1. Dacarro C, Picco AM, Grisoli P, Rodolfi M (2003) Determination of aerial microbiological contamination in scholastic sports environments. J Appl Microbiol 95:904-912. https://doi.org/10.104 6/j.1365-2672.2003.02044.x

2. Madureira J, Aguiar L, Pereira C, Mendes A, Querido MM, Neves P, Teixeira JP (2018) Indoor exposure to bioaerosol particles: levels and implications for inhalation dose rates in schoolchildren. Air Qual Atmos Health 11:955-964. https://doi.org/10.1007/s1186 9-018-0599-8

3. Hwang SH, Kim IS, Park WM (2017) Concentrations of PM10 and airborne bacteria in daycare centers in Seoul relative to indoor environmental factors and daycare center characteristics. Air Qual Atmos Health 10:139-145. https://doi.org/10.1007/s1186 9-016-0423-2

4. Larsson K, Malmberg P, Eklund L, Belin L, Blaschke E (1988) Exposure to microorganisms, airway inflammatory changes and immune reactions in asymptomatic dairy farmers. Int Arch
Allergy Immunol 87:127-133. https://doi.org/10.1159/00023 4662

5. Aaron Fernstrom MG, Fernstrom A, Goldblatt M (2013) Aerobiology and its role in the transmission of infectious diseases. J Pathog 2013:493960. https://doi.org/10.1155/2013/493960

6. Guan D, Guo C, Li Y, Lv H, Yu X (2015) Study on the concentration and distribution of the airborne bacteria in indoor air in the lecture theatres at Tianjin Chengjian University, China. Procedia Eng 121:33-36. https://doi.org/10.1016/j.proeng.2015.08.1015

7. D'Arcy N, Cloutman-Green E, Lai KM, Margaritis D, Klein N, Spratt DA (2014) Potential exposure of children to environmental microorganisms in indoor healthcare and educational settings. Indoor Built Environ 23:467-473. https://doi.org/10.1177/14203 26X14527018

8. World Health Organization (WHO) (2009) WHO guidelines for indoor air quality: dampness and mould. WHO Regional Office for Europe, Copenhagen, Denmark

9. Xie Z, Li Y, Lu R, Li W, Fan C, Liu P, Wang J, Wang W (2018) Characteristics of total airborne microbes at various air quality levels. J Aerosol Sci 116:57-65. https://doi.org/10.1016/J.JAERO SCl.2017.11.001

10. Bates MN, Chandyo RK, Valentiner-Branth P, Pokhrel AK, Mathisen M, Basnet S, Shrestha PS, Strand TA, Smith KR (2013) Acute lower respiratory infection in childhood and household fuel use in Bhaktapur, Nepal. Environ Health Perspect 121:637642. https://doi.org/10.1289/ehp.1205491

11. Wickramasinghe AP, Karunaratne DGGP, Sivakanesan R (2011) PM10-bound polycyclic aromatic hydrocarbons: concentrations, source characterization and estimating their risk in urban, suburban and rural areas in Kandy, Sri Lanka. Atmos Environ 45:2642-2650. https://doi.org/10.1016/j.atmosenv.2011.02.067

12. Prussin AJ, Marr LC (2015) Sources of airborne microorganisms in the built environment. Microbiome 3:78. https://doi. org/10.1186/s40168-015-0144-z

13. World Health Organization (2009) WHO Guidelines for indoor air quality: dampness and mould. ISBN 7989289041683

14. Zhang G, Neumeister-Kemp H, Garrett M, Kemp P, Stick S, Franklin $P$ (2013) Exposure to airborne mould in school environments and nasal patency in children. Indoor Built Environ 22:608-617. https://doi.org/10.1177/1420326X12447534

15. Alves C, Duarte M, Ferreira M, Alves A, Almeida A, Cunha Â (2016) Air quality in a school with dampness and mould problems. Air Qual Atmos Health 9:107-115. https://doi.org/10.1007/s1186 9-015-0319-6

16. Pronczuk J, Surdu S (2008) Children's environmental health in the twenty-first century. Ann NY Acad Sci 1140:143-154. https ://doi.org/10.1196/annals.1454.045

17. Denny FW, Loda FA (1986) Acute respiratory infections are the leading cause of death in children in developing countries. Am J Trop Med Hyg 35:1-2

18. Asghar SA, Srivastava MR, Srivastava JP, Gupta P, Zaidi ZH (2017) Prevalence of acute respiratory infections among children under five years of age attending rural health training centre of Era's Lucknow Medical College and Hospital. Int J Community Med Public Health 4:3752. https://doi.org/10.18203/2394-6040.ijcmp h20174245

19. Nguyen TKP, Nguyen DV, Truong TNH, Tran MD, Graham SM, Marais BJ (2017) Disease spectrum and management of children admitted with acute respiratory infection in Viet Nam. Trop Med Int Health 22:688-695. https://doi.org/10.1111/tmi.12874

20. World Health Organization (2010) Communicable disease epidemiological profile: Sri Lanka. World Health Organization, Geneva. http://apps.who.int/iris/bitstream/10665/70514

21. Ferkol T, Schraufnagel D (2014) The global burden of respiratory disease. Ann Am Thorac Soc 11:404-406. https://doi. org/10.1513/AnnalsATS.201311-405PS 
22. Danansuriya MN, Rajapaksa LC, Weerasinghe A (2015) Genetic, familial and environmental correlates of asthma among early adolescents in Sri Lanka: a case control study. World Allergy Organ J 8:1-7. https://doi.org/10.1186/s40413-015-0068-x

23. Rannan-Eliya RP (2008) Population ageing and health expenditure: Sri Lanka 2001-2101 Research Studies Series, Number 2 Institute for Health Policy, Colombo, Sri Lanka

24. Passos SD, Gazeta RE, Felgueiras AP, Beneli PC, Coelho MSZS (2014) Do pollution and climate influence respiratory tract infections in children? Rev Assoc Med BRAs 60:276-283. https://doi. org/10.1590/1806-9282.60.03.018

25. Weerasundara L, Amarasekara RWK, Magana-Arachchi DN, Ziyath AM, Karunaratne DGGP, Goonetilleke A, Vithanage M (2017) Microorganisms and heavy metals associated with atmospheric deposition in a congested urban environment of a developing country: Sri Lanka. Sci Total Environ 584-585:803-812. https://doi. org/10.1016/J.SCITOTENV.2017.01.121

26. Napoli C, Marcotrigiano V, Montagna MT (2012) Air sampling procedures to evaluate microbial contamination: a comparison between active and passive methods in operating theatres. BMC Public Health 12:1. https://doi.org/10.1186/1471-2458-12-594

27. Bowers RM, Lauber CL, Wiedinmyer C, Hamady M, Hallar AG, Fall $\mathrm{R}$, Knight R, Fierer N (2009) Characterization of airborne microbial communities at a high-elevation site and their potential to act as atmospheric ice nuclei. Appl Environ Microbiol 75:5121-5130. https://doi.org/10.1128/AEM.00447-09

28. Somerville W, Thibert L, Schwartzman K, Behr MA (2005) Extraction of Mycobacterium tuberculosis DNA: a question of containment. J Clin Microbiol 43:2996-2997. https://doi.org/10.1128/ JCM.43.6.2996-2997.2005

29. Ma R, Wu X, Wang R, Wang C, Zhu J (2008) Identification and phylogenetic analysis of a bacterium isolated from the cloaca of Chinese alligator. Afr J Biotechnol 7:2128-2133

30. Chen C-Y, Lai C-Y, Kuo M-H (2009) Temperature effect on the growth of Buchnera endosymbiont in Aphis craccivora (Hemiptera: Aphididae). Symbiosis 49:53-59. https://doi.org/10.1007/ s13199-009-0011-4

31. U.S. EPA. Exposure Factors Handbook (2011) U.S. Environmental Protection Agency, Washington, DC, EPA/600/R-09/052F

32. Mirhoseini SH, Nikaeen M, Satoh K, Makimura K (2016) Assessment of airborne particles in indoor environments: applicability of particle counting for prediction of bioaerosol concentrations. Aerosol Air Qual Res 16:1903-1910. https://doi.org/10.4209/ aaqr.2015.08.0528

33. Puspitasari F, Maki T, Shi G, Bin C, Kobayashi F, Hasegawa H, Iwasaka $Y$ (2016) Phylogenetic analysis of bacterial species compositions in sand dunes and dust aerosol in an Asian dust source area, the Taklimakan Desert. Air Qual Atmos Health 9:631-644. https:// doi.org/10.1007/s11869-015-0367-y

34. Flores GE, Bates ST, Knights D, Lauber CL, Stombaugh J, Knight R, Fierer N (2011) Microbial biogeography of public restroom surfaces. PLoS ONE. https://doi.org/10.1371/journal.pone.0028132

35. National Academies of Sciences E and M (2017) Microbiomes of the built environment. National Academies Press, Washington, D.C.

36. Ana GR, Fakunle GA, Ogunjobi AA (2015) Indoor airborne microbial burden and risk of acute respiratory infections among children under five in Ibadan, Nigeria. Indoor Built Environ 24:308314. https://doi.org/10.1177/1420326X13499171

37. Tang JW (2009) The effect of environmental parameters on the survival of airborne infectious agents. J R Soc Interface 6(Suppl 6):S737-S746. https://doi.org/10.1098/rsif.2009.0227.focus

38. Bisgaard H, Hermansen MN, Bønnelykke K, Stokholm J, Baty F, Skytt NL, Aniscenko J, Kebadze T, Johnston SL (2010) Association of bacteria and viruses with wheezy episodes in young children: prospective birth cohort study. BMJ 341:c4978. https://doi. org/10.1136/bmj.c4978
39. Baquero F, Alvarez M-E, Cantón R (1996) Bacteriologic diagnosis of respiratory tract infection. Clin Microbiol Infect 1:2S10-2S15. https://doi.org/10.1111/j.1469-0691.1996.tb00185.x

40. Iglewski BH (1996) Medical microbiology, 4th edn. University of Texas Medical Branch at Galveston, Galveston

41. Carmona F, Fábregues F, Alvarez R, Vila J, Cararach V (1992) A rare case of chorioamnionitis by Morganella morganii complicated by septicemia and adult respiratory distress syndrome. Eur J Obstet Gynecol Reprod Biol 45:67-70. https://doi.org/10.1016/00282243(92)90196-6

42. Tuazon CU, Murray HW, Levy C, Solny MN, Curtin JA, Sheagren JN (1979) Serious infections from Bacillus sp. JAMA J Am Med Assoc 241:1137. https://doi.org/10.1001/jama.1979.03290370041026

43. Eduard W, Heederik DJJ, Melbostad E, Mehl R, Douwes J (2001) Short term exposure to airborne microbial agents during farm work: exposure-response relations with eye and respiratory symptoms. Occup Environ Med 58:113-118

44. Burge $H$ (1990) Bioaerosols; Prevalence and health effects in the indoor environment. J Allergy Clin Immunol 86(5):687-701

45. Qian J, Hospodsky D, Yamamoto N, Nazaroff WW, Peccia J (2012) Size-resolved emission rates of airborne bacteria and fungi in an occupied classroom. Indoor Air 22:339-351. https://doi.org/10.1 111/j.1600-0668.2012.00769.x

46. Rubin RH, Young LS (2002) Clinical approach to infection in the compromised host. Plenum, New York

47. Tringe SG, Zhang T, Liu X, Yu Y, Lee WH, Yap J, Yao F, Suan ST, Ing SK, Haynes M, Rohwer F, Wei CL, Tan P, Bristow J, Rubin EM, Ruan $Y$ (2008) The airborne metagenome in an indoor urban environment. PLoS ONE 3:e1862. https://doi.org/10.1371/journ al.pone.0001862

48. Humbal C, Joshi SK, Trivedi UK, Gautam S (2019) Evaluating the colonization and distribution of fungal and bacterial bio-aerosol in Rajkot, western India using multi-proxy approach. Air Qual Atmos Health. https://doi.org/10.1007/s11869-019-00689-6

49. Mai-Prochnow A, Clauson M, Hong J, Murphy AB (2016) Gram positive and Gram negative bacteria differ in their sensitivity to cold plasma. Sci Rep 6:38610. https://doi.org/10.1038/srep38610

50. Osman S, Peeters Z, La Duc MT, Mancinelli R, Ehrenfreund P, Venkateswaran K (2008) Effect of shadowing on survival of bacteria under conditions simulating the martian atmosphere and UV radiation †. Appl Environ Microbiol 74:959-970. https://doi. org/10.1128/AEM.01973-07

51. Tong Y, Lighthart B (1997) Solar radiation has a lethal effect on natural populations of culturable outdoor atmospheric bacteria. Atmos Environ 31:897-900. https://doi.org/10.1016/S1352 -2310(96)00235-X

52. Psoter KJ, De Roos AJ, Wakefield J, Mayer J, Rosenfeld M (2013) Season is associated with Pseudomonas aeruginosa acquisition in young children with cystic fibrosis. Clin Microbiol Infect 19:E483E489. https://doi.org/10.1111/1469-0691.12272

53. Lu C, Deng Q, Ou C, Liu W, Sundell J (2013) Effects of ambient air pollution on allergic rhinitis among preschool children in Changsha, China. Chin Sci Bull 58:4252-4258. https://doi.org/10.1007/ s11434-013-5725-2

54. Fuentes-Leonarte V, Ballester F, Tenías JM (2009) Sources of indoor air pollution and respiratory health in preschool children. J Environ Public Health 2009:1-19. https://doi.org/10.1155/2009/727516

55. Nandasena S, Wickremasinghe AR, Sathiakumar N (2012) Respiratory health status of children from two different air pollution exposure settings of Sri Lanka: a cross-sectional study. Am J Ind Med 55:1137-1145. https://doi.org/10.1002/ajim.22020

Publisher's Note Springer Nature remains neutral with regard to jurisdictional claims in published maps and institutional affiliations. 